Article

\title{
Architectural Design: Sustainability in the Decision-Making Process
}

\author{
Margarida Feria ${ }^{1}$ and Miguel Amado ${ }^{2, *(1)}$ \\ 1 GEOTPU.LAB - Laboratory of Architecture, Territory and Urban Planning Studies of IST, 1049-001 Lisboa, \\ Portugal; margaridadcferia@gmail.com \\ 2 CERIS, Civil Engineering Research and Innovation for Sustainability of Universidade de Lisboa, \\ Av Rovisco Pais 1, 1049-001 Lisboa, Portugal \\ * Correspondence: miguelpamado@tecnico.ulisboa.pt
}

Received: 8 April 2019; Accepted: 22 May 2019; Published: 27 May 2019

\begin{abstract}
This article discusses the potential of introducing sustainability in the architectural design method so that building solutions can contribute to sustainable development. Sustainability has introduced a new pattern to the architecture practice, which involves important modifications in the teaching of architecture in what regards to the design methods to students but also practitioners, in order to provide more comfort for present and future generations. In the design phases of the architectural design, the subject of the three pillars of sustainability-economic, social and environmental factors - are not always considered by the architect in the decision-making process. The topic involves actions that will influence the overall performance of the building throughout its lifecycle. Sustainability has not been a priority in the training of the architect. The existing tools, Sustainability Assessment and Certification Systems, although adequate to evaluate the sustainability component of a building, do not prove to be the most appropriate tool to support architects during the design process. Therefore, the implementation and evaluation of strategies that integrate the sustainability principles need to be included in the early stages of the architectural design method. In addition to collecting data through literature review, a survey was conducted among 217 architects and architecture students in order to access the need for a tool that supports architects in the issue of sustainability. The results concluded that, although all the respondents agree about what concerns the implementation of sustainability principles in the architectural design method, only few respondents guarantee that these principles are implemented by means of a rigorous evaluation. Thus, the purpose of this paper is to identify a set of guidelines that can help architects to change the current approach of architectural practice towards more sustainable strategies in building design. This means the introduction, implementation and evaluation of sustainability principles in different phases of the architectural design method. The proposal stresses the main strategies that need to be considered in each phase of the architectural project and defines a level of recommendation in each guideline that allows the architect to evaluate the implementation of sustainability.
\end{abstract}

Keywords: sustainability; guidelines; architectural design method; Assessment and Certification Systems; survey

\section{Introduction}

The current state of global development poses new challenges to the architectural profession: it must transform and adapt itself in order to ensure a role with greater relevance in the search for effective sustainable solutions.

In this sense, it is important to understand the connection of the architect with the sustainable development, because his relationship with the design practice of the architect sustainability is 
introduced in the paradigm of architecture as a necessity that entails important modifications in the teaching of architecture as well as the design methods of students and practitioners in order to provide prosperity for present and future generations.

Over the last decades, it has been substantiated that the excessive consumption of natural resources surpasses their replacement time. This scenario is not viable to maintain a balance between the needs of human activities and their adaptation to the environment to guarantee future conditions of enjoyment for the upcoming generations. Since the construction industry is responsible for the exploitation of $50 \%$ of the world's natural resources $[1,2]$ it is also one of the sectors that could most contribute to the reduction of environmental impacts.

According to UNESCO and International Union of Architects (UIA), Charter for Architectural Education, "... architecture involves everything that influences the way in which the built environment is planned, designed, made, used, furnished, landscaped and maintained" and so " ... architectural education constitutes some of the most significant environmental and professional challenges of the contemporary world" [3].

It is expected that the construction sector will continue to grow in the next years as housing demand increases globally [4]. According to The Global Status Report 2017, over the next 40 years, the sector floor area of buildings will double, adding more than 230 billion square meters in new construction [5]. Therefore, it is important, as a global measure, to know how societies' development models can maximize sustainability in order to foster social, economic and technological progress with the efficient use of natural resources and energy. To achieve this goal, it is necessary to change the current approach of architectural practice towards more sustainable strategies in building design. This means that the practice of architects should be re-designed to accommodate a better understanding of the effects of climate change in a rapidly urbanization process and an economic crisis [6].

\section{Literature Review}

The principle of sustainable development emerged as a response to the general panorama at the end of the 20th century, which was characterized by rapid industrial development and the considerable increase of the world population [7] that led to an uncontrolled exploitation of natural resources.

Since the 1970s, a set of international political agendas have been proposed, calling for cooperation between nations and the various sectors of human activities. The Brundtland Report has become one of the most important reflections on sustainable development since it allied the need for economic growth to environmental and social issues. Also called "Our Common Future", the Brundtland Report was released in 1987 by the World Commission on Environment and Development of United Nations and defined for the first time the concept of sustainable development as " $(\ldots)$ development that meets the needs of the present without compromising the ability of future generations to meet their own needs" [8]. The interpretation of Brundtland's definition suggests that to acknowledge the sustainable component of a building, it is important to consider the environmental, social and economic dimensions of sustainability.

In 1994, the concept of sustainable construction first appeared during the First International Conference on Sustainable Construction in Tampa, Florida, where different approaches were communicated towards a definition of sustainable construction. At the conference, Charles Kibert presented the concept of greater consensus for the sustainable construction sector, defining it as "the creation and operation of a healthy built environment based on ecological principles and resource efficiency" [9], considering soil, materials, energy and water as the most important resources for construction. It is from these resources that architects need to establish the use of the following principles to a sustainable construction [10]:

- Minimization of resource consumption;

- Reduction of maintenance necessities;

- Recycling of materials at the end of the building life cycle;

- Protection of natural systems and their function in all activities; 
- Promotion of the quality of the built environment.

Throughout the building life cycle, sustainable construction presents multiple advantages. It has a positive impact on the environment through energy conservation, saving water and other resources, use of reusable, natural and local materials, reducing pollutant emissions, recycling life cycle waste of the constructions and increasing building durability [11,12]. It also has positive social effects: guaranteeing users' health and comfort through indoor air quality and acoustics comfort, as well as accessibility, security and preservation of cultural heritage. Moreover, sustainable construction also provides economic benefits in the long-term.

The role of sustainable construction is also reinforced by Sustainability Assessment and Certification Systems that allow estimations of the level of efficiency and sustainability achieved by improving the quality and performance of buildings. These systems evaluate environmental, economic and social dimensions of sustainability and are greatly increasing the attention towards sustainable assessment of buildings [13-15].

Even though sustainability assessment tools are valuable to verify if a building is sustainable, they are mostly developed to evaluate the construction only after it is built and are not suitable to assist architects in building design because they do not approach specific strategies to guide practitioners [16-19]. Also, the possibility to reduce negative impacts of a building is greater in the design phase, when approximately $80 \%$ of the building consumption is defined [10].

Since the decisions made during the design phase will influence the building's performance throughout the rest of its lifecycle, it is important that architects consider sustainability principles during the design process. This is possible through the linked and weighted implementation of preventive and passive strategies over active strategies [20]. Also, architectural professionals have an important role to future low energy in sustainable buildings, since it is in the design phase were the decisions take place [21].

The implementation of such strategies can be aided by a tool that can support architects in the implementation of sustainability principles during the architectural design process [22].

\subsection{Architectural Design Methods}

The design studio is the most effective architectural education and methodological training tool. The studio functions as a pedagogic constructor in which acquired knowledge and skills are applied in the design process through problem solving.

It is predicted that in the design studio the application of previous theoretical knowledge and the acculturation, which influences the definition of the concept, will allow the architect to find the solution to the problem.

Rapid development in the knowledge generated and the empowerment promoted, skills, methods and tools for the design domain have a direct impact on the way the activities are conducted in the studio [23]. It is important to consider the learning process of design in the studio as one that in its practice assumes a form of collaborative work and knowledge integration.

Architectural education must inspire creativity and innovation, but also dialogue, inclusivity and critical thinking to reinforce determination towards operative communication and team collaboration [24].

It is very important that the education in architecture is sufficiently strong, so that the students acquire skills and competencies to deal with the sustainability issues in the future [18-25].

There are different perspectives on the architect's role in the process of creating and transforming spaces. On the other hand, the origin of ideas, decisions, values and selected references are attitudes depending on a personal understanding of the reality of all the principles of sustainability [26].

In this paper we do not consider the activity of the architect who does not design but still has an administrative role in public activities.

Sustainable principles need to be consciously integrated into the architectural design method to establish a solid and coherent foundation for sustainability throughout the remaining life cycle of the 
building [10]. Architectural design methods must be studied in order to understand how they can adapt to the requirements of the present and the needs of the future.

In the field of architecture, there is a lack of a body of theory to support the study of architectural design methods $[27,28]$. Thus, it is essential to review and reinterpret concepts from other fields of study. [29-32] identify the following normative models, currently used in urban planning, as some of the most important: Synoptic or Rational Comprehensive, Incremental, Transactive and Advocatory. However, within the field of existing planning models, it is still fundamental to mention the Scientific Method that is widely used by architects.

Table 1, adapted from the work of [30] to fit the scope of architecture, compares the theoretical planning models regarding their relation to the promotion of sustainable development in architecture. It can be concluded that, although the models may contribute to the implementation of some strategies that promote sustainability, none of them reflect a direct tendency towards the aims of sustainable development. This in turn suggests that there is the need to analyze a new planning model, integrable in the architectural design method, which adheres to the framework of all the principles of sustainable development.

Table 1. Schematic overview of various planning theories.

\begin{tabular}{cccccc}
\hline Header & $\begin{array}{c}\text { Global/National } \\
\text { Environmental and } \\
\text { Resource Concerns }\end{array}$ & $\begin{array}{c}\text { Local } \\
\text { Environmental } \\
\text { Concerns }\end{array}$ & $\begin{array}{c}\text { Fair } \\
\text { Distribution } \\
\text { of Benefits }\end{array}$ & $\begin{array}{c}\text { Respect for Human, } \\
\text { Political and Civil } \\
\text { Rights }\end{array}$ & $\begin{array}{c}\text { Potential for } \\
\text { Change of Societal } \\
\text { Frame Conditions }\end{array}$ \\
\hline Synoptic & $(+)$ & $(-)$ & $(+)$ & $(-)$ & $X$ \\
Incremental & - & - & - & $(+)$ & $(+)$ \\
Transactive & $(-)$ & $(+)$ & $(+)$ & + & + \\
Advocatory & $X$ & + & $(-)$ & + & + \\
Scientific & $(+)$ & $(+)$ & $(-)$ & $X$ & $(+)$ \\
\hline
\end{tabular}

+ usually well suited, (+) may be suited under certain condition, $\mathrm{X}$ no evidence, $(-)$ may cause negative effects; - usually has negative effects. Source: [30] (adapted).

Architectural design methods require a simpler, flexible and inclusive planning model that provides a connection with the objectives of sustainable development and therefore anticipates the long-term effects of constructions in the environment.

Considering that the architectural design method complements at least four phases: program definition, feasibility study, preliminary design and detail design, each of these phases is implemented by a decision-making process which involves: analysis, synthesis, evaluation and decision [31,33-35]).

Ref. [36] consider the method as being a multidimensional construction of a more processual nature and identify indicators of academic engagement from a multilateral perspective as three stand points: behavioral, cognitive and affective.

Regarding architectural design methods, they contemplate sustainability issues, the phases of analysis and whether synthesis should be responsible for the implementation of sustainable principles, while the evaluation phase should validate the conformity of the hypotheses with the established principles (Figure 1). As concluded by the developed survey, the evaluation phase is often empirical or non-existent among architects, which exposes the lack of a systemic assessment method with a theoretical basis that can guide architects during the assessment phase [37]. 


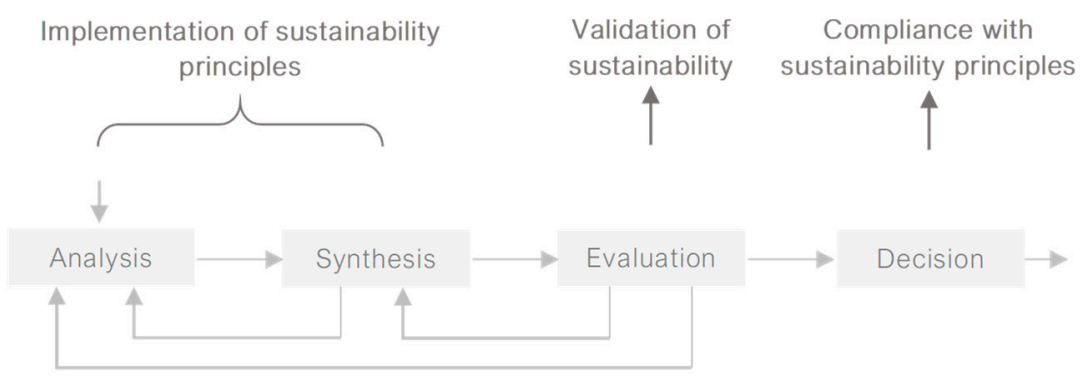

Figure 1. Decision-making process to implement sustainability. Source: [34] (adapted).

\subsection{Key Indicators of Sustainability in Architectural Design}

In order to measure the sustainability of the implemented solutions, key indicators must be identified. These indicators ensure that all principles and components of sustainability are systematically considered in the architectural design method. Although Sustainability Assessment and Certification Systems "are not originally designed to serve as design guidelines" (Ding, 2008:456), it is possible to rely on these tools to identify key indicators that can measure the sustainability of various solutions during the design process.

Sustainability Assessment and Certification Systems are technical instruments that identify, predict and evaluate the environmental impact of buildings and then assign a level of certification related to the accomplishment of sustainability principles [14,38]. The evaluation of most of these systems is based on the attribution of credits or points when certain parameters are met. These parameters are organized by categories and vary according to the assessment system. Each category is given a specific weight according to its importance in relation to the level of sustainability in construction. The sum of the various scores attributed to each category results in a graded classification for the sustainable performance of the building.

According to different studies $[38,39]$ that compare different assessment and certification systems, the categories that present the highest weights are the environmental loading, internal environment, external environmental impact and resources. In general, the areas most linked to the environmental component are more relevant compared to socioeconomic and political factors, planning and innovation.

The weightings of the systems are determined according to the degree of importance assigned to each of the categories of evaluation, and these are directly related to the situations of each country. Among the several systems, the energy efficiency requirement is consistently assigned a higher value as it is recognized as one of the most urgent needs. Great importance is also given to the nature of the materials, conservation of potable water and to parameters related to indoor environmental comfort such as visual, thermal and acoustic comfort as well as indoor air quality.

Based on these weightings and considering the architects' thinking-process in architectural design, the following five key sustainability indicators were selected: energy efficiency, potable water conservation, indoor air quality, acoustic comfort and project durability. These were considered the most representative and suitable to be integrated in the methodological framework of architectural design methods [40].

By implementing strategies that contemplated the selected five key indicators, in all the phases of the architectural design method, other sustainability parameters could be determined, but also the sustainability of the project could be guaranteed.

\section{Research Methodology}

This research combines theoretical and empirical evidence, that is, establishment of a theoretical framework in order to ensure the adequacy on an empirical and holistic approach. The methodology has been defined to allow the understanding of the relationship of the design practice of the architect with the sustainability. In this way, the research adopts a sequence of four steps that enabled to quantify 
the principal factors considered by architects and architecture students in introducing sustainability issue in the architectural design.

In its first step, the research was done at the level of the presuppositions for the understanding of the architect's knowledge of Sustainable Development and its relationship with the architect's design practice. The fact that architecture involves a huge number of relations between the natural and built environment as well as the social requirements of human activities, through which the main factors need to be identified for their efficient performance in design. To reach an understanding of the current state of the real necessities of architects and the advantages of existing system to help to implement the principles of sustainability in design, the research considered the definition of a list of indicators that can be representative of sustainable development applied to architecture design [10]. The second step of the research process has been a development of a survey to professional architects and architecture students from different countries and with different backgrounds, with the objective to create a framework of the skills they must have to deal with the subject of sustainability applied to design [41]. The third step was assessing the group of indicators related to sustainable principles that must be considered in all design processes conducted by the architects who participate in the fourth step of the research process with the proposal of guidelines to assist their practice.

This research resulted in the identification and formulation of a structure of design phases and a list of guidelines supported in a strategic thinking of architect to implement sustainability in design (Figure 2).

\begin{tabular}{|l|l|}
\hline STEP 1 & Literature review \\
\hline STEP 2 & Survey \\
\hline STEP 3 & Selection of indicators \\
\hline STEP 4 & Proposal of guidelines \\
\hline
\end{tabular}

Figure 2. Research method.

\section{Survey}

The actors involved in the design of architectural projects and the trainers of future architects need to collaborate and develop new and different teaching approaches that promote skills and competences for future professional practice. The requirement that sustainability introduces in the design process demands from the architect the ability to develop strategies and new guidelines for the project.

The opportunity for the architect to work with a multidisciplinary team requires new ways and means of communication. Engineers and architects possess such skills, however, most architects do not know how to restore to empirical tools or bypass the deeper approach without a visible result.

The opportunity to extend the set of principles introduced in the design process reduces the communication issues between architects and engineers, leading to new ways in which the more humanistic, philosophical and cultural approach to architecture is able to proceed towards the positivist attitude of the engineer where subjectivity is non-existent.

An online survey was conducted to assess architectural professionals and architecture students to analyze and understand their viewpoints and opinions about the necessities on the advantages of creating a system that can support architects in the implementation of sustainability principles in the design process [41].

The developed survey yielded 217 responses and the statistical results are presented in Table A1. The survey and the number of questions are sufficient and sensibly effective to obtain data related to what issues are of importance and what architects do to deal with sustainability as well as what method they apply.

All the respondents $(100 \%)$ considered that sustainability should be implemented in the architectural design process (Question 2), even though approximately $46 \%$ of them said that they evaluated the implementation of sustainability empirically and $30 \%$ of the respondents do not evaluate 
the sustainability component of their projects at all (Question 3). This indicates that a systematic evaluation, with a theoretical foundation, is not part of most respondents' architectural design methods.

When asked if Sustainability Assessment and Certification Systems were adequate to support architects during the design phase (Question 4), only 26\% of the respondents considered these factors appropriate, whereas most of the respondents (72\%) did not know. When questioned about which of the methods was most effective to ensure the implementation of sustainability (Question 5), almost half $(49.3 \%)$ stated that the Systematic methods with theoretical foundations adapted to architectural design process was the best one and approximately a third (31.8\%) of them admitted not knowing. It is crucial to notice that, although $46 \%$ of the inquired said that they used an Empirical Method to evaluate the implementation of sustainability, only $3 \%$ considered it the most suitable method.

To provide respondents with the opportunity to express additional opinion, one optional open-ended question enabled them to write any comments related to what they consider necessary for developing guidelines for a sustainable project.

Overall, it can be understood that, although all the respondents agree that sustainability principles should be implemented in the architectural design process, only few respondents guarantee that these principles are implemented by means of a rigorous evaluation. This, in turn, highlights the need for a system that supports architects in guaranteeing sustainability as an integral part of architectural design method.

\section{Guidelines to Sustainable Architecture Design}

Implementing sustainability into architectural design methods requires sustainability principles to be considered from the beginning of the design process [42]. In order to assist architects in selecting the best strategies and verify their alignment with the aims of sustainability, guidelines for a sustainable project have been developed. These guidelines were determined from the previously selected key indicators of sustainability [43].

An integrated approach to sustainability leads to a design solution where the technical aspects are inserted into the design process. In the sketching phase, the project becomes better defined and the indoor environmental conditions and the energy frame of the building are starting to become determined by the design [44]. This decision is also important for the level of comfort, and for a quality working environment for future users. From an economic point of view, the operating costs can be reduced to a minimum when the climate screen of the building considers passive strategies, thus, saving energy for cooling and heating, and the passive ventilation principles employed also reduce energy consumptions.

Therefore, it is important that the design process takes into account the passive strategies in different phases of the operative process:

Analysis-site analysis (history, architecture, genius loci, green structures, infrastructure, equipment and facilities in the area and the social structure of inhabitants). Comfort analysis (based on CR 1752). Climate analysis (solar data and calculations of altitude and azimuth, temperature, rainfall, humidity, prevalent wind). Regulation analysis of legislative demands (building codes and municipality documents).

Sketching-Site plan. Solar simulations of site plan in order to identify shadows from buildings and other volumes. Green roofs to save rain water and influence the level of humidity. Daylight levels in the middle of the buildings and glare risk. Identify the $U$-values to the site and uses requirement (insulation thickness). Simulation of heating and cooling load. Ventilation passive strategies (natural ventilation, dimension and placement of windows). Atriums in relation to entrance area in the dwellings. Open floor plans. Construction system (structure). Physical models or virtual models to help to understand the scale and shape.

Synthesis-Ventilation passive strategies (natural ventilation, dimension and placement of windows). Calculation of the heating and cooling load. Selection of interior materials based on space acoustic performance. Criteria selection of materials based on Life Cycle Assessment (LCA) balance. 
Calculation of a structural detail (timber, iron or concrete). Calculation of minimal ventilation rate and the opening area of the windows to maximize the result. Physical models or virtual models.

All of these different parameters were integrated in the design process at various stages as tools rather than obstacles. These principles need to be understood as a natural part of the design process.

In this context, the proposed guidelines summarize and evaluate the main strategies and principles that need to be integrated throughout various design methods phases to ensure that sustainability principles are considered in the architectural design process [45]. Each guideline was given a recommendation level, outlined in Table A2, to specify the degree of importance of implementing each strategy. Moreover, additional specifications for certain guidelines have been included for further explanations or suggestions where necessary.

Each strategy has been integrated into one of the four phases of the architectural design method according to its level of detail. However, the presented guidelines admit multiple interactions and feedback loops between various design phases according to the thinking process of each architect.

If possible, the architect should always prioritize the implementation of passive strategies. In addition, the final decisions concerning the implementations of each strategy must be treated responsibly and adapted to the context of the site.

The structure of the proposed guidelines is presented in Table 2 and the guidelines can be found in the Table A2 and Supplementary Materials.

Table 2. Guidelines Structure.

\begin{tabular}{l}
\hline \multicolumn{1}{c}{ Guidelines Structure } \\
\hline Table I. Program and Data Collection \\
Passive Strategies \\
\hline i. Site and Climate \\
ii. Urban Context and Conditions \\
iii. Adapting the program to the site \\
iv. Internal consumption and needs \\
v. Other Criteria \\
\hline Table II. Feasibility Study \\
Passive Strategies \\
\hline i. Siting \\
ii. Orientation \\
iii. Form \\
iv. Envelope \\
v. Landscape \\
\hline Table III. Preliminary Design \\
Passive Strategies \\
\hline i. Structure \\
ii. Internal layout \\
iii. Opening elements \\
iv. Shading elements \\
v. Natural Ventilation \\
vi. Additional energy efficient strategies \\
\hline Active Strategies \\
\hline vii. Heating and Cooling Solutions \\
\hline Table IV. Detailed Design \\
Passive Strategies \\
\hline i. Materials Selection \\
ii. Thermal Insulation Materials \\
iii. Construction Details \\
iv. Water Fixtures \\
v. Building Management \\
\hline Active Strategies \\
\hline vi. Low Consumption Devices Selection \\
\hline
\end{tabular}




\section{Program and Data Collection}

The program is the starting point of any architecture project, when the general requirements of the overall design are defined. To guarantee the sustainability of the project, the architect should consider the bioclimatic characteristics of the site [46-48] as well as the best energy efficiency strategies and the possibility for potable water conservation. Impermeabilized areas should be minimized and adapted to the profile and number of users, functions of the future building and typology of spaces in order to reduce damage in ecosystems and natural resources. It is also important to estimate internal consumption and needs of the future building and to study other significant criteria concerning social, cultural and economic context.

\section{Feasibility Study}

The feasibility phase is crucial to ensure energy efficiency, since it determines how the building is formally integrated in the surrounding environment. Issues such as orientation and form, determined in this phase, will have a huge impact on the energy performance of the building in the operation phase. Therefore, it is important to prioritize daylighting, natural ventilation and passive design solutions for heating and cooling, using mass, landscaping and design to work with topography and climate $[46,47,49]$.

\section{Preliminary Design}

In the preliminary design phase, the design team experiments with internal layout, dimensioning of areas and heights, and elements regarding the envelope of the building as opening elements and shading systems. These decisions are key determinants for the energy efficiency of the building.

Active strategies for heating and cooling systems, powered by renewable resources, should also be addressed so that such systems can form an integral part of the building and the use of prefabrication [50].

\section{Detail Design}

In the detail design phase, final considerations are decided regarding the layout and dimension of interior spaces. Materials and finishing materials, water fixtures, electrical equipment and artificial lighting are selected. This phase is still very important for the implementation of sustainability since these strategies will have a great impact on acoustic comfort, indoor air quality, energy efficiency and durability of the building. Moreover, water fixtures choice will impact potable water conservation [51].

The previous guideline structure defines a contribution for a more sustainable solution of architecture design, that can be achieved through management of many principles that should be considered and integrated in the project by the creation of more holistic approach [52].

The results show that there will be a positive impact on this relevant theme about guidelines on sustainable design architecture.

\section{Conclusions}

Sustainability can be understood as a set of ethical values based on social, environmental and economic responsibility. Through these values, it is possible to reach sustainable development, which, should urgently emerge to replace the current development model of societies.

The practice of architecture is a driver to achieve sustainable development, yet most architects do not address this issue in their projects. The study of architectural design methods reveals the need for a new, simpler, multidisciplinary model that implements sustainability within the design process. An evaluation of the sustainability component in the design process who is often nonexistent among architects or it lacks a systematic and theoretically based evaluation methods. This understanding highlights the results of the survey where almost half (49.3\%) of the survey respondents stated that the Systematic methods with theoretical foundations adapted to architectural design process was the best one even though approximately a third (31.8\%) of them admitted not knowing. 
In response to this need, an evaluation system was developed, formalized in guidelines, which were structured according to the phases of the architectural design process. These guidelines inform architects of the main strategies required to achieve sustainability goals as well as to optimize the design process.

The guidelines are also suitable for determining whether a building contributes for sustainable development.

Furthermore, the aim to raise awareness regarding the sustainability in the field of architecture still very rarely implemented. Thus, the proposed system suggests a transition from a theoretical concept to one that can be practiced and conducted to the implementation of a more sustainable architecture design with strategies and tools in practice, and with support from informative guidelines built for architects and other technics and stakeholders.

The guidelines raise several possibilities for future developments and adaptations by the architects. They can evolve into an interactive model in the form of a checklist, which helps to reduce the error and the risk in the decision phase. In addition, the content of the guidelines could be further developed and expanded to include other sustainability indicators more focused on the social and economic dimensions of sustainability.

Another outcome would be the computerization of the developed tool or its incorporation in a 3D design software for architecture. This would allow the design team to more accurately evaluate the implementation of sustainability principles while developing technical drawings and visualizations. Such evaluations would not only include the assessment of energy performance of a building, as it is already done by several software programs, but also other key indicators of sustainability.

Supplementary Materials: The following are available online at http://www.mdpi.com/2075-5309/9/5/135/s1, Table S1: PROGRAM AND DATA COLLECTION; Table S2: FEASIBILITY STUDY; Table S3: PRELIMINARY DESIGN, Table S4: DETAIL DESIGN.

Author Contributions: Concept and development of research, M.F.; concept, structure of the research method and revision of the text, M.A.

Funding: This research received no external funding.

Conflicts of Interest: The authors declare no conflict of interest.

\section{Appendix A}

Table A1. Statistics of respondents.

1. Clarify your professional situation:

\begin{tabular}{lc}
\hline Answer & Ratio \\
\hline Architecture student. & $32.3 \%$ \\
Architect and is responsible for designing projects. & $37.3 \%$ \\
Architect and collaborates in the design of projects. & $22.1 \%$ \\
Architect but does not practice the profession. & $8.3 \%$ \\
\hline
\end{tabular}

2. Do you think that the concept of sustainability should be contemplated during architecture design process?

\begin{tabular}{lc}
\hline Answer & Ratio \\
\hline Yes. & $100 \%$ \\
No. & $0 \%$ \\
\hline
\end{tabular}

3. How do you evaluate the implementation of sustainability in your projects during the design process?

\begin{tabular}{lc}
\hline Answer & Ratio \\
\hline I evaluate empirically. & $45.6 \%$ \\
I use an evaluation system developed by me or my team. & $13.8 \%$ \\
I use commercial evaluation systems (i.e., LiderA, LEED, BREEAM, CASBEE). & $7.8 \%$ \\
I do not evaluate. & $30.0 \%$ \\
Other. & $2.8 \%$ \\
\hline
\end{tabular}


Table A1. Cont.

4. In your opinion, are commercial sustainability assessment and certification systems (i.e., LEED, BREEAM, CASBEE) adequate to support the design phase of the project?

\begin{tabular}{lc}
\hline Answer & Ratio \\
\hline Yes. & $25.8 \%$ \\
No. & $2.3 \%$ \\
I do not know. & $71.9 \%$ \\
\hline
\end{tabular}

5. Which of the following methods do you consider most effective to ensure the implementation of sustainability into the architectural design process?

\begin{tabular}{lc}
\hline Answer & Ratio \\
\hline Empirical methods. & $3.7 \%$ \\
Systematic methods with theoretical foundations adapted to architectural design process. & $49.3 \%$ \\
Sustainability commercial evaluation systems (i.e., LiderA, LEED, BREEAM, CASBEE). & $13.8 \%$ \\
I do not know. & $31.8 \%$ \\
Other method. & $1.4 \%$ \\
\hline
\end{tabular}

6. Please add any comments on what you consider necessary for developing guidelines to a sustainable project.

\begin{tabular}{ll}
\hline Answer & Ratio \\
\hline Open answers & $97.0 \%$ \\
\hline
\end{tabular}

Table A2. Levels of Recommendations for Guidelines for a sustainable project.

\begin{tabular}{c}
\hline Levels of Recommendations \\
\hline Is recommended \\
Should be considered \\
May be considered \\
\hline
\end{tabular}

\section{References}

1. Anink, D.; Boonstra, C.; Mak, J. Handbook of Sustainable Building: An Environmental Preference Method for Selection of Materials for Use in Construction and Refurbishment; James \& James: London, UK, 1996; p. 8.

2. Edwards, B.; Hyett, P. Guía Básica de la Sostenibilidad (Basic Guide to Sustainability); Editorial Gustavo Gili: Barcelona, Spain, 2004.

3. UIA The International Union of Architects. Changing Architectural Education for Reaching Sustainable Future: A Contribution to the Discussion. 2011. Available online: https://www.researchgate.net/publication/270464664_ Changing_architectural_education_For_reaching_sustainable_future_A_contribution_to_the_discussion (accessed on 1 November 2018).

4. IEA. Tracking Clean Energy Progress 2017: Excerpt Informing Energy Sector Transformations. OECD Countries: International Energy Agency. 2017, pp. 54-57. Available online: https:/www.iea.org/publications/ freepublications/publication/TrackingCleanEnergyProgress2017.pdf (accessed on 2 August 2018).

5. United Nations Environment and IEA. Towards a Zero-Emission, Efficient, and Resilient Buildings and Construction Sector. Global Status Report 2017. Available online: http://www.worldgbc.org/sites/default/ files/UNEP188_GABC_en\%28web\%29.pdf (accessed on 20 August 2018).

6. Amado, M.; Ramalhete, I.; Freitas, J.C.; Amado, A.R.; Silva, A. Towards the Sustainable City: A Model to Transform the Informal into Formal. In Transactions on Ecology and the Environment, Ecosystems and Sustainable Development XI; WIT: Wessex, UK, 2017.

7. Roser, M.; Ortiz-Ospina, E. Global Extreme Poverty. 2017. Available online: https://ourworldindata.org/ extreme-poverty (accessed on 25 May 2018).

8. WCED. Our Common Future. World Commission on Environment and Development; Oxford University Press: Oxford, UK, 1987.

9. Kibert, C. The next generation of sustainable construction. Build. Res. Inf. 2007, 35, 595-601. [CrossRef]

10. Amado, M.; Reaes Pinto, A.; Alcafache, A.; Ramalhete, I. Construção Sustentável: Conceito e Prática; Caleidoscopio, Casal de Cambra: Lisboa, Portugal, 2015. (In Portuguese) 
11. Osmani, M.; Glass, J.; Price, A.D.F. Architects' perspectives on construction waste reduction by design. Waste Manag. 2008, 28, 1147-1158. [CrossRef] [PubMed]

12. Pitt, M.; Tucker, M.; Riley, M.; Longden, J. Towards sustainable construction: Promotion and best practices. Construct. Innov. Inf. Process Manag. 2009, 9, 201-224. [CrossRef]

13. Hastings, R.; Wall, M. Sustainable Solar Housing, Vol I: Strategies and Solutions; Earthscan: London, UK, 2007; pp. 37-46.

14. Berardi, U. Sustainability Assessment in the Construction Sector: Rating Systems and Rated Buildings. Sustain. Dev. 2011, 20, 411-424. [CrossRef]

15. Lamorgese, L.; Geneletti, D. Sustainability Principles in Strategic Environmental Assessment: A Framework for Analysis and Examples from Italian Urban Planning. Environ. Impact Assess. Rev. 2013, 42, 116-126. [CrossRef]

16. Ding, G. Sustainable construction: The role of environmental assessment tools. J. Environ. Manag. 2008, 86, 451-464. [CrossRef] [PubMed]

17. Kim, D.; Dong, K.; Lee, J.; Shin, J.; Chung, H.; Jo, H. A development of a simplified energy assessment tool for residential buildings. Int. Conf. Sustain. Build. Asia 2013, 446, 217-225.

18. Markelj, J.; Kuzman, M.; Grošelj, P.; Zbašnik-Senegačnik, M. A simplified method for evaluating building sustainability in the early design phase for architects. Sustainability 2014, 6, 8775-8795. [CrossRef]

19. Bergman, D. Sustainable Design: A Critical Guide; Princeton Architectural Press: New York, NY, USA, 2011; ISBN 978-1568989419.

20. Guy, S.; Farmer, G. Reinterpreting Sustainable Architecture: The Place of Technology. J. Archit. Educ. 2011, 54, 140-148. [CrossRef]

21. Kanters, J.; Horvat, M.; Dubois, M. Tools and methods used by architects for solar design. Energy Build. 2014, 68, 721-731. [CrossRef]

22. Han, J.H.; Kim, S.S. Architectural Professionals' Needs and Preferences for Sustainable Building Guidelines in Korea. Sustainability 2014, 6, 8379-8397. [CrossRef]

23. Truta, C.; Parv, L.; Topala, I. Academic Engagement and Intention to Drop Out: Levers for Sustainability in Higher Education. Sustainability 2018, 10, 4637. [CrossRef]

24. Lopes, A.C.; Farinha, J.; Amado, M. Sustainability through Art, International Conference on Technologies and Materials for Renewable Energy, Environment and Sustainability; TMREES 2017; Energy Procedia; Salame, C.-T., Aillerie, M., Panagiotis, P., Eds.; Elsevier Science BV: Amsterdam, The Netherlands, 2017; Volume 119, pp. 752-766.

25. Leal, F.W.; Raath, S.; Lazzarini, B.; Vargas, V.R.; de Souza, L.; Anholone, R.; Quelhas, O.L.G.; Haddad, R.; Klavins, M.; Orlovici, V.L. The role of transformation in learning and education for Sustainability. J. Clean. Prod. 2018, 199, 286-295. [CrossRef]

26. Brophy, V.; Lewis, O.J. A Green Vitruvius Principles and Practice of Sustainable Architectural Design; Routledge: London, UK, 2011.

27. Bay, J.; Ong, B. Tropical Sustainable Architecture: Social and Environmental Dimensions; Architectural Press: Oxford, MS, USA, 2006; pp. 15-27.

28. Plowright, P.D. Revealing Architectural Design: Methods, Frameworks and Tools; Routledge: New York, NY, USA, 2014; pp. 1-69.

29. Hudson, B.; Galloway, T.; Kaufman, J. Comparison of current planning theories: Counterparts and contradictions. J. Am. Plan. Assoc. 1979, 45, 387-398. [CrossRef]

30. Næss, P. Normative Planning Theory and Sustainable Development. Scand. Hous. Plan. Res. 1994, 11, 145-167. [CrossRef]

31. Moughtin, C.; Rafael, C.; Sarris, C.; Signoretta, P. Urban Design: Method and Techniques; Architectural Press: Oxford, MS, USA, 1999.

32. Watson, D.; Plattus, A.J.; Shibley, R.G.; Watson, D. (Eds.) Time-Saver Standards for Urban. Design; McGraw-Hill: New York, NY, USA, 2003.

33. Amado, M. Planeamento Urbano Sustentável; Editorial Caleidoscopio Casal de Cambra: Lisboa, Portugal, 2005. (In Portuguese)

34. Lawson, B. How Designers Think: The Design Process Demystified, 4th ed.; Architectural Press: Oxford, MS, USA, 2005.

35. Ryan, C. Traditional Construction for a Sustainable Future; Routledge: Abingdon, UK, 2011. 
36. Appleton, J.J.; Christenson, S.L.; Furlong, M.J. Student engagement with school: Critical conceptual and methodological issues of the construct. Psychol. Sch. 2008, 45, 369-386. [CrossRef]

37. Park, J.; Yoon, J.; Kim, K.H. Critical Review of the Material Criteria of Building Sustainability Assessment Tools. Sustainability 2017, 9, 186. [CrossRef]

38. Bernardi, E.; Carlucci, S.; Cornaro, C.; Bohne, R. An Analysis of the Most Adopted Rating Systems for Assessing the Environmental Impact of Buildings. Sustainability 2017, 9, 1226. [CrossRef]

39. Lucas, V.; Amado, M.P. Advantages of the Certification of Sustainable Construction. In Proceedings of the 1st International Conference on Building Sustainability Assessment, Porto, Portugal, 23-25 May 2012; Amôeda, R., Mateus, R., Bragança, L., Pinheiro, C., Eds.; Green Lines Institute for Sustainable Development: Porto, Portugal, 2012. ISBN 978-989-95671-7-7.

40. John, G.; Clements-Croome, D.; Jeronimidis, G. Sustainable building solutions: A review of lessons from natural world. Build. Environ. 2005, 40, 319-328. [CrossRef]

41. Bunz, K.R.; Henze, G.P.; Tiller, D.K. Survey of Sustainable Building Design Practices in North America, Europe, and Asia. J. Archit. Eng. 2006, 12, 33-62. [CrossRef]

42. National Institute of Building Sciences [NIBS]. Whole Building Design Guide (WBDG); National Institute of Building Sciences: Washington, DC, USA, 2014; Available online: https://www.wbdg.org/ffc/nibs (accessed on 20 August 2018).

43. Ofei-Manu, P.; Didham, R.J. Identifying the factors for sustainability learning performance. J. Clean. Prod. 2018, 198, 1173-1184. [CrossRef]

44. Jensen, S.R.; Kamari, A.; Strange, A.; Kirkegaard, P.H. Towards a holistic approach to retrofitting: A critical review of state-of-the-art evaluation methodologies for architectural transformation. In Proceedings of the WSBE 2017 (World Sustainable Built Environment) Conference, Hong Kong, China, 5-7 June 2017.

45. Potbhare, V.; Syal, M.; Kormaz, S. Adoption of Green Building Guidelines in Developing Countries Based on U.S.; India Experiences. J. Green. Build. 2009, 4, 158-174. [CrossRef]

46. Brown, G.Z.; DeKay, M. Sun, Wind \& Light: Architectural Design Strategies, 2nd ed.; Jonh Wiley \& Sons: New York, NY, USA, 2001.

47. Olgyay, V. Design with Climate: Bioclimatic Approach to Architectural Regionalism; Princeton University Press: Princeton, NJ, USA; Oxford, MS, USA, 2015.

48. Akadiri, P.O.; Chinyio, E.A.; Olomolaiye, P.O. Design of A Sustainable Building: A Conceptual Framework for Implementing Sustainability in the Building Sector. Buildings 2012, 2, 126-152. [CrossRef]

49. Cofaigh, E.; Olley, J.; Lewis, J. The Climatic Dwelling: An Introduction to Climate-Responsive Residential Architecture; James \& James: London, UK, 1996.

50. Veira, N.; Amado, M.; Pinho, F. Prefabricated solution to modular construction in Cape Verde. In Proceedings of the Technologies and Materials For Renewable Energy, Environment and Sustainability: Tmrees16-Cnam, Paris, France, 16-18 November 2016; Salame, C.-T., Ferroud, C., Descombes, G., Aillerie, M., Faucheux, S., Eds.; AIP Conference Proceedings: College Park, MD, USA, 2016; Volume 1814, ISBN 978-0-7354-1482-2. [CrossRef]

51. Das, O.; Bera, P.; Moulick, S. Water Conservation Aspects of Green Buildings. Int. J. Res. Eng. Technol. 2015, 4, 75-79.

52. Shan, M.; Hwang, B.G. Green Building rating systems: Global reviews of practices and research efforts. Sustain. Cities Soc. 2018, 39, 172-180. [CrossRef]

(C) 2019 by the authors. Licensee MDPI, Basel, Switzerland. This article is an open access article distributed under the terms and conditions of the Creative Commons Attribution (CC BY) license (http://creativecommons.org/licenses/by/4.0/). 